\title{
Relationship Between Compressive Strength and Splitting Tensile Strength of Palm Kernel Shell Concrete
}

\author{
${ }^{1}$ Odeyemi, S. O., ${ }^{2,3}$ Atoyebi, O. D., ${ }^{4 * A j a m u ~ S . ~ O ., ~ a n d ~}{ }^{5}$ Adesina, A. \\ ${ }^{1}$ Department of Civil and Environmental Engineering, Kwara State University, Malete, Kwara State, Nigeria. \\ ${ }^{2}$ Landmark University SDG 11 (Sustainable Cities and Communities Research Group). \\ ${ }^{3}$ Department of Civil Engineering, Landmark University, Omu-Aran, Kwara State, Nigeria. \\ 4*Department of Civil Engineering, Ladoke Akintola University of Technology, Ogbomoso, Oyo State, Nigeria. \\ ${ }^{5}$ Civil Engineering Department, University of Windsor, Windsor, Canada.
}

*Corresponding author E-mail: soajamu@lautech.edu.ng; $\quad$ Tel.: +2347038862164

Submitted on: $28 / 09 / 2021$

Accepted on: $30 / 09 / 2021$

\begin{abstract}
The use of palm kernel shell (PKS) has gained acceptance in the production of concrete. Compressive strength is the mostly used strength characteristics of concrete. The compressive strength CS of concrete should provide a good basis for predicting the splitting tensile strength STS. The aim of this study is to establish a mathematical relationship between the CS and STS of concrete produced with PKS. In this study, coarse aggregates was fully replaced with PKS at varying water-cement ratios $(w / c)$ for concrete mix ratios 1:11/2:3 and 1:2:4. Unit weigth of the $P K S$, slump, compressive and splitting tesnsile strength were determined. A relationship between CS and STS was developed for the different $w / c$ ratios using exponential function aproximation. Physical property tests carried out on the PKS characterized it as lightweight aggregate with saturated surface dry unit weight of 1.27. The slump revealed that PKS concrete at 0.3 and $0.4 \mathrm{w} / \mathrm{c}$ is stiff and not workable. CS and STS at 28day for mix ratio of 1:11/2:3 at w/c of 0.3, 0.4, 0.5 and 0.6 were respectively 3.2 and 1.2; 9.4 and $2.1 ; 10.8$ and 2.6; 9.0 and $2.4 \mathrm{~N} / \mathrm{mm}^{2}$. The corresponding values obtained for mix ratio 1:2:4 were 3.0 and 1.0, 1.7 and 1.3, 4.5 and 1.6, 7.7 and $1.9 \mathrm{~N} / \mathrm{mm}^{2}$, respectively. Equations relating CS and STS at 0.3, 0.4, 0.5 and $0.6 \mathrm{w} / \mathrm{c}$ were established. It was concluded that PKS concrete produced with mix ratios 1:11/2:3 and 1:2:4 performed better in compression and splitting tensile strength at $w / c$ of 0.5 and 0.6.
\end{abstract}

Keywords: Compressive strength, Splitting tensile strength, Concrete, Palm Kernel Shells, Water-cement ratios

\section{Introduction}

The construction industry relies primarily on traditional materials such as cement, granite and sand for concrete production (Odeyemi et al., 2015, 2020). To a very large extent, their high and increasing costs have inhibited the creation of shelters and other infrastructural facilities in developing countries; hence, the need for engineering consideration for the use of locally available materials to meet the required need for improved self-efficiency, leading to a reduction in the cost of construction for sustainable development (Adesina and Atoyebi, 2020; Atoyebi et al., 2018, 2020). Palm Kernel Shell (PKS) is an example of such locally available materials. It is a by-product from palm oil production and a waste material that can be used in the production of lightweight concrete. PKS is derived from the oil palm tree (elaeis guineesis), an economically viable tree, predominant in West Africa and widespread in Nigeria (Ndoke, 2006; Oyedepo et al., 2015). Nuhu-Koko (1990) reported that about 1.5 million tonnes of PKS are produced annually in Nigeria and this generated about $70 \%$ of wastes in areas where they are produced which may constitute an environmental hazard.

The accumulation of these wastes can be reduced to the minimum if they are used as a substitute for coarse aggregates in concrete works. This will help to solve a growing waste disposal crisis such as environmental pollution leading to health hazards. Equally, there will be a reduction in the cost of construction works if non-conventional local materials like PKS are used as a replacement for conventional coarse aggregates. Also, the space of land used as deposit points for the shells will be available for other economic use. The use of lightweight concrete using PKS will result in significant cost savings, reduction in structural dead loads, thinner structural plate sections, reduced size of 
structural members and fewer reinforcing steel (Atoyebi et al., 2018). The use of PKS in concrete has been investigated by several researchers (Chandra and Berntsson, 2003; Mannan and Ganapathy, 2002; Odeyemi et al., 2019; Olanipekun et al., 2006; Olutoge, 2010; Teo et al., 2007). They reported the suitability of using it as a complete replacement for granite in lightweight concrete. However, there is paucity of information on relationship bwteen CS and STS of PKS concrete for predicting values of STS fron known values of CS. Thus, this paper aims to determine the relationship between CS and STS of PKS concrete at varying water-cement ratios.

\section{Materials and Methods}

The materials used in this research consist of fine aggregate (river sand), coarse aggregate (PKS), cement and water. The river sand was sourced from a river bed in Ilorin, Kwara State, while the PKS were obtained from a local palm oil-producing mill in Osogbo, Osun State while Dangote cement brands (42.5R) of Ordinary Portland Cement which conforms to (NIS 444-1:2003) were purchased from a cement vendor in Ilorin. The river sand was freed of deleterious particles contained in it. The PKS was prepared by washing with detergent, drying and freed of dirt, oil and mud particles that adhered to its surface. The samples were tested for their physical properties at the Soil and Concrete Laboratory of the Federal Polytechnic Offa, Offa, Kwara State. The physical properties examined were particle size distribution, specific gravity, fineness modulus, aggregate impact value, aggregate crushing value and water absorption capacity.

The particle size distribution of the aggregates was carried out using British standard (BS) sieves that conforms to BS EN 12620:2002+A1:2008. The specific gravity and water absorption of the materials was determined by using the procedures as outlined in (BS 812-1: 1995). Specific gravity (SG) was calculated using Equation 1.

$$
S G=\frac{W_{2}-W_{1}}{\left(W_{4}-W_{1}\right)-\left(W_{3}-W_{1}\right)}
$$

Where: $\mathrm{W}_{1}$ is the weight of empty bottle, $\mathrm{W}_{2}$ is the weight of bottle with aggregate samples, $\mathrm{W}_{3}$ is the weight of bottle with the aggregate and water and $\mathrm{W}_{4}$ is the weight of bottle with water.

The fineness modulus was conducted using the procedure as outlined n BS EN 933-1 (BS EN 933-1, 2012). The aggregate impact value and aggregate crushing value were also conducted following (BS EN 1097-2, 2013; Neville, 2011).

Batching of the various materials for concrete production was done by volume. The workability of the fresh concrete produced from the two mix ratios considered was carried out in accordance with provision of BS EN 12350-2 (2019) while the compressive strength test was carried out in accordance with provision of BS EN 12390-3 (2002) and the splitting tensile strength was carried out using BE EN 12390-6 (2000).

\section{Results and Discussion}

The results of the particle size distribution for the river sand and PKS used in this research, are as presented in Figure 1 and Figure 2, respectively. From Figure 1 and 2, the Coefficient of Uniformity for the river sand and PKS were obtained to be 10 and 1.82 respectively. This implies that the river sand is well-graded while the PKS is uniformly graded. 
LAUTECH Journal of Civil and Environmental Studies

Volume 7, Issue 2; September 2021

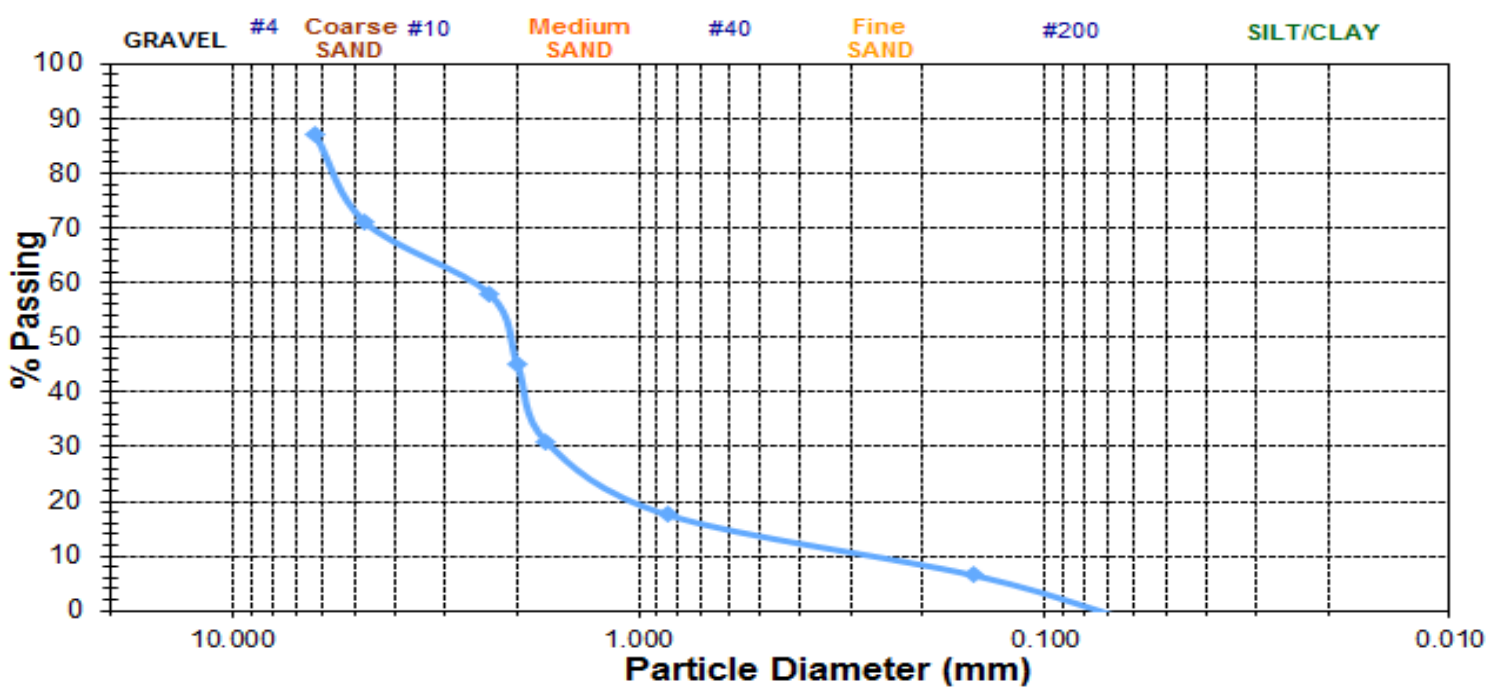

Figure 1: - Particle size distribution for sand

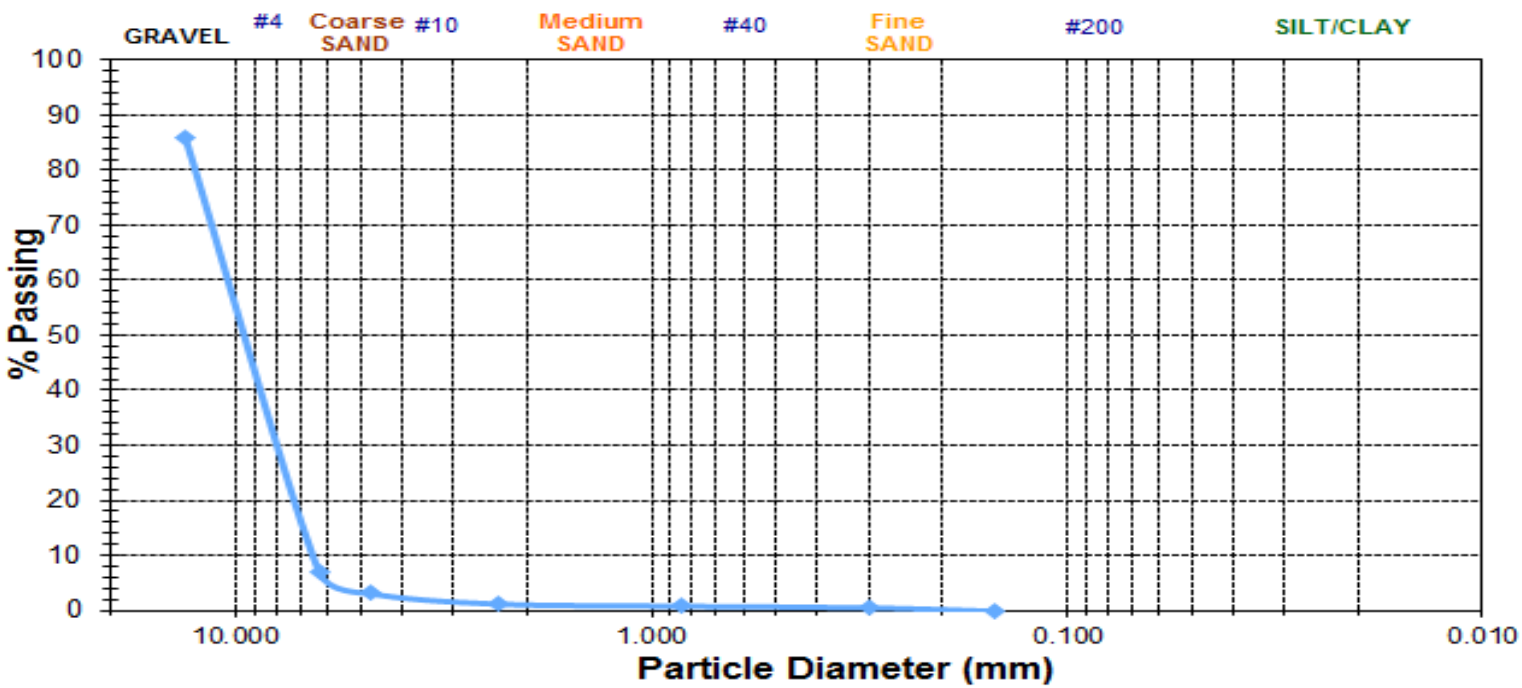

Figure 2: - Particle size distribution for PKS

The physical properties for the PKS used in this study are shown in Table 1. The values obtained are in close agreement with those reported by Basri, et al. (1998) and also fall within the range specified for lightweight aggregates by BS EN 12620:2002+A1:2008.

Table 1: Physical properties for PKS

\begin{tabular}{clll}
\hline S/No & Property & Value & Unit \\
\hline 1 & Fineness Modulus & 6.01 & - \\
2 & Specific gravity & 1.27 & - \\
3 & Aggregate Impact Value & 2.25 & $\%$ \\
4 & Water Absorption Capacity (in 24 hours) & 16.2 & $\%$ \\
5 & Aggregate Crushing Value & 4.33 & $\%$ \\
\hline
\end{tabular}

The slump test results for the fresh concrete at varying w/c for mix ratio $1: 1 \frac{1}{2}: 3$ and $1: 2: 4$ are as presented in Figure 3 and 4 respectively. The results showed that the slump of PKS concrete increases 
as w/c ratio increases. The slump was zero $(0)$ at w/c of 0.3 and 0.4 for both mixes indicating that the concrete was stiff and not workable for these w/c ratios.

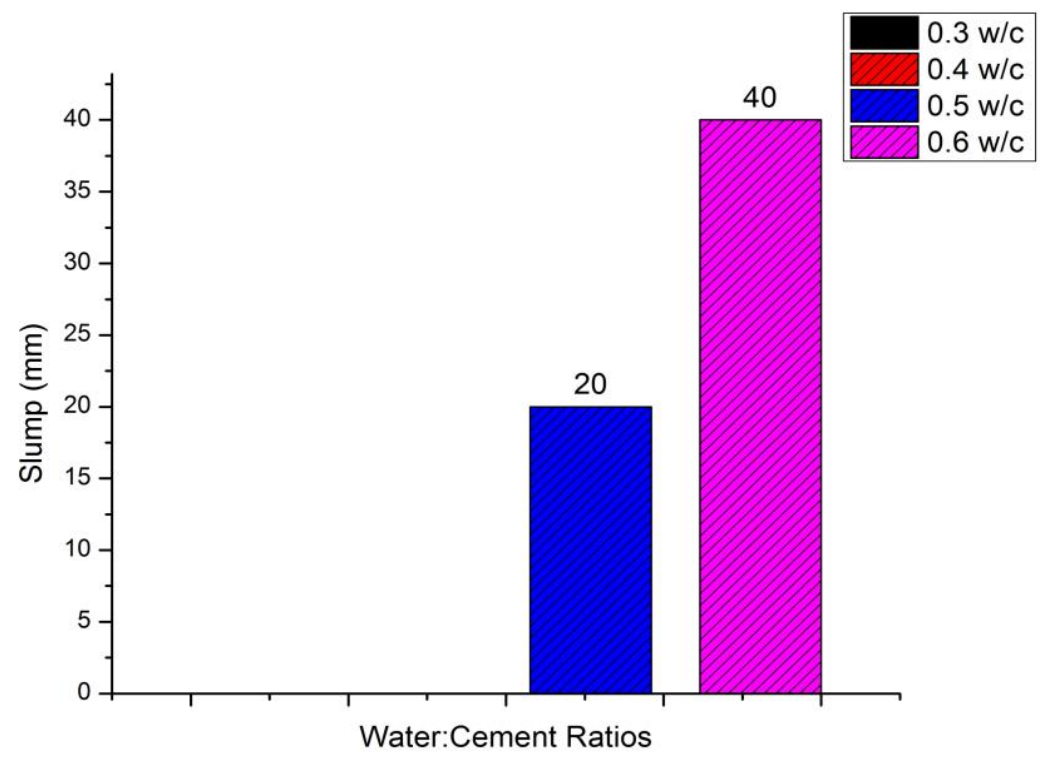

Figure 3: - Slump for Mix Ratio 1: $1 \frac{1}{2}: 3$

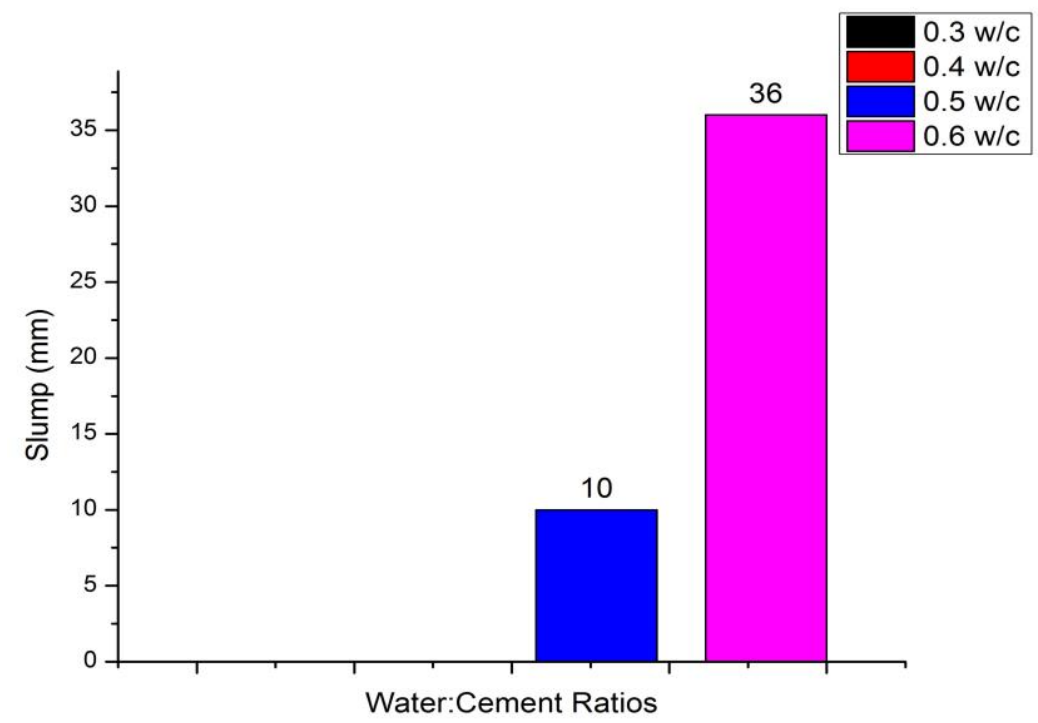

Figure 4: - Slump for Mix Ratio 1:2: 4

The CS and STS results obtained at 7, 14 and 28 days for w/c ratio $0.3,0.4,0.5$ and 0.6 for mix ratio 1:11/2:3 and 1:2:4 are shown in Table 2. For the w/c ratios considered in this study, these values were plotted to obtain the relationship between the strengths considered i.e CS and STS. Figure 5 shows the relationship between them for mix ratio 1:11/2:3 while Figure 6 shows the relationship between CS and STS for mix ratio 1: 2: 4 for different w/c.

For the two mix ratios and for all w/c used, the results obtained for STS and CS as presented in Tables 2 to 5 show that STS values is about 20 to $23 \%$ of their coresponding CS values.

Table 2: Compressive and Splitting Tensile Strength Results for 0.3 W/C Ratio PKS Concrete

\begin{tabular}{ccccc}
\hline \multirow{2}{*}{ Days } & \multicolumn{2}{c}{ Mix Ratio $\left[1: 1 \frac{1}{2}: 3\right]$} & \multicolumn{2}{c}{ Mix Ratio [1:2: 4] } \\
\cline { 2 - 5 } & $\mathrm{CS}\left(\mathrm{N} / \mathrm{mm}^{2}\right)$ & $\mathrm{STS}\left(\mathrm{N} / \mathrm{mm}^{2}\right)$ & $\mathrm{CS}\left(\mathrm{N} / \mathrm{mm}^{2}\right)$ & $\mathrm{STS}\left(\mathrm{N} / \mathrm{mm}^{2}\right)$ \\
\hline 7 & 2.4 & 0.8 & 1.1 & 0.3 \\
14 & 3.0 & 1.0 & 2.8 & 0.8 \\
28 & 3.2 & 1.2 & 3.0 & 1.0 \\
\hline
\end{tabular}


LAUTECH Journal of Civil and Environmental Studies

Volume 7, Issue 2; September 2021

Table 3: Compressive and Splitting Tensile Strength Results for 0.4 W/C Ratio PKS Concrete

\begin{tabular}{ccccc}
\hline \multirow{2}{*}{ Days } & \multicolumn{2}{c}{ Mix Ratio $\left[1: 1 \frac{1}{2}: 3\right]$} & \multicolumn{2}{c}{ Mix Ratio $[1: 2: 4]$} \\
\cline { 2 - 5 } & $\mathrm{CS}\left(\mathrm{N} / \mathrm{mm}^{2}\right)$ & $\mathrm{STS}\left(\mathrm{N} / \mathrm{mm}^{2}\right)$ & $\mathrm{CS}\left(\mathrm{N} / \mathrm{mm}^{2}\right)$ & STS $\left(\mathrm{N} / \mathrm{mm}^{2}\right)$ \\
\hline 7 & 6.5 & 1.5 & 3.9 & 1.0 \\
14 & 7.4 & 2.0 & 5.0 & 1.1 \\
28 & 9.4 & 2.1 & 7.7 & 1.3 \\
\hline
\end{tabular}

Table 4: Compressive and Splitting Tensile Strength Results for 0.5 W/C Ratio PKS Concrete

\begin{tabular}{ccccc}
\hline \multirow{2}{*}{ Days } & \multicolumn{2}{c}{ Mix Ratio $\left[1: 1 \frac{1}{2}: 3\right]$} & \multicolumn{2}{c}{ Mix Ratio [1: 2: 4] } \\
\cline { 2 - 5 } & $\mathrm{CS}\left(\mathrm{N} / \mathrm{mm}^{2}\right)$ & $\mathrm{STS}\left(\mathrm{N} / \mathrm{mm}^{2}\right)$ & $\mathrm{CS}\left(\mathrm{N} / \mathrm{mm}^{2}\right)$ & STS $\left(\mathrm{N} / \mathrm{mm}^{2}\right)$ \\
\hline 7 & 9.7 & 2.4 & 3.5 & 1.4 \\
14 & 10.3 & 2.5 & 3.9 & 1.5 \\
28 & 10.8 & 2.6 & 4.5 & 1.6 \\
\hline
\end{tabular}

Table 5: Compressive and Splitting Tensile Strength Results for 0.6 W/C Ratio PKS Concrete

\begin{tabular}{ccccc}
\hline \multirow{2}{*}{ Days } & \multicolumn{2}{c}{ Mix Ratio $\left[1: 1 \frac{1}{2}: 3\right]$} & \multicolumn{2}{c}{ Mix Ratio Mix Ratio $[1: 2: 4]$} \\
\cline { 2 - 5 } & $\mathrm{CS}\left(\mathrm{N} / \mathrm{mm}^{2}\right)$ & $\mathrm{STS}\left(\mathrm{N} / \mathrm{mm}^{2}\right)$ & $\mathrm{CS}\left(\mathrm{N} / \mathrm{mm}^{2}\right)$ & STS $\left(\mathrm{N} / \mathrm{mm}^{2}\right)$ \\
\hline 7 & 6.7 & 1.7 & 5.4 & 1.5 \\
14 & 8.3 & 2.0 & 7.0 & 1.8 \\
28 & 9.0 & 2.4 & 7.7 & 1.9 \\
\hline
\end{tabular}

\section{Relationship between STS and CS for mix ratio of 1:1/2 at different w/c}

Figure 5 shows relationship between STS and CS for mix ratio of 1:11/2:3 using exponential approximation. The relationship between STS and CS is as presented by trendline equations.

STS vs CS for Mix Ratio of 1:11/2:3 at Different w/c

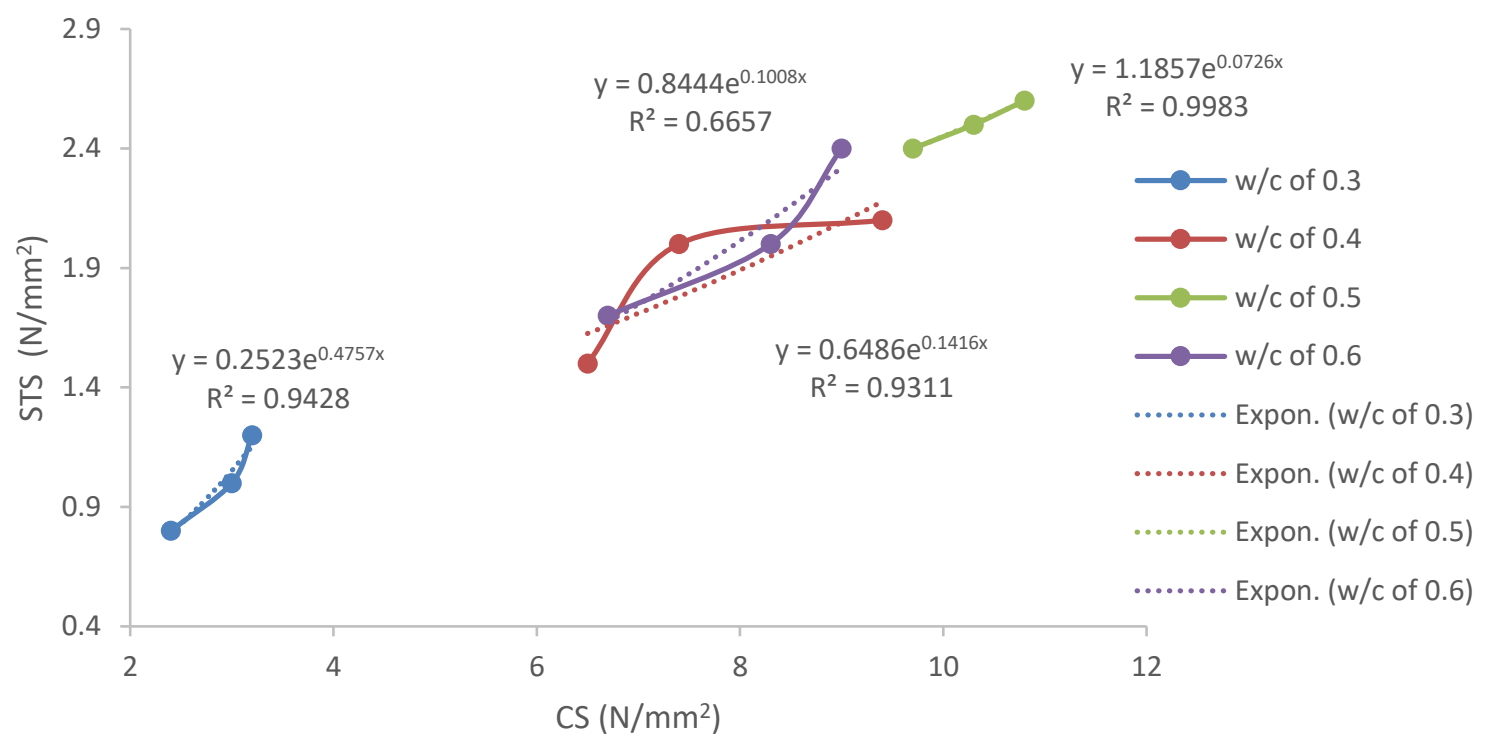

Figure 5: STS vs CS for Mix Ratio of 1:11/2:3 at Different w/c 
Figure 6 shows relationship between STS and CS for mix ratio of 1:2:4 using exponential approximation. The relationship between STS and CS is as presented by trendline equations.

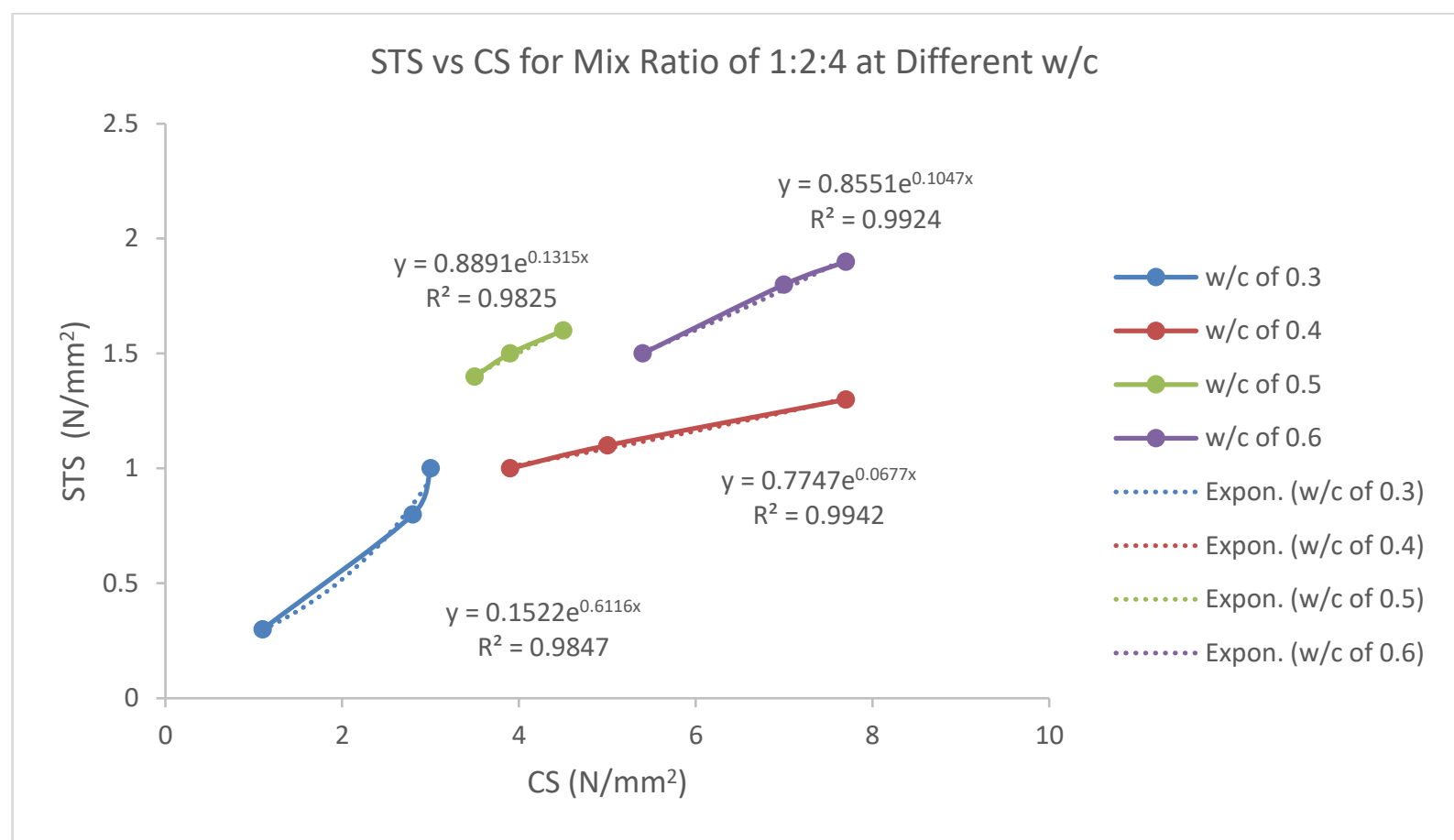

Figure 6: Relationship between CS and STS for Mix Ratio 1:2:4 at Different w/c

The equations relating the CS and the STS of PKS concrete at $0.3,0.4,0.5$ and $0.6 \mathrm{w} / \mathrm{c}$ ratios for mix ratios 1:1 1/2:3 and 1:2:4 are shown in Table 6 and Table 7 respectively.

Table 6: Equations relating CS and STS for PKS Concrete with mix ratio of Mix ratio 1:11/2:3

\begin{tabular}{clc}
\hline w/c Ratio & Relationship & $\mathrm{R}^{2}$ Value \\
\hline 0.3 & $y=0.2523 e^{0.4757 x}$ & 0.9428 \\
0.4 & $y=0.8444 e^{0.1008 x}$ & 0.6657 \\
0.5 & $y=1.1857 e^{0.0726 x}$ & 0.9983 \\
0.6 & $y=0.6486 e^{0.1416 x}$ & 0.9311 \\
\hline
\end{tabular}

Table 7: Equations relating CS and STS for PKS Concrete with mix ratio of Mix ratio 1:2:4

\begin{tabular}{clc}
\hline w/c Ratio & \multicolumn{1}{c}{ Relationship } & $\mathrm{R}^{2}$ Value \\
\hline 0.3 & $y=0.1522 e^{0.6116 x}$ & 0.9847 \\
0.4 & $y=0.7747 e^{0.0677 x}$ & 0.9942 \\
0.5 & $y=0.8891 e^{0.1315 x}$ & 0.9825 \\
0.6 & $y=0.8551 e^{0.1047 x}$ & 0.9924 \\
\hline
\end{tabular}

Where $y$ represents the STS and $x$ the corresponding value of CS of PKS concrete of a particular mix ratio and w/c, for all $x$ (i.e. CS) greater than zero which is expected because CS cannot be zero. Tables 6 and 7 show that mix ratio and w/c used for PKS concrete production determine the relationships to be chosen for predicting values of STS from known values of CS.

\section{Conclusion}

The relationship between the compressive and split tensile strength of PKS concrete has been investigated in this study and the following conclusions are made:

(i) Slump of PKS concrete increases as w/c ratio increases for mix ratios 1:11/2:3 and 1:2:4. 
(ii) Slump for PKS concrete at w/c ratio of 0.3 and 0.4 is zero for both mixes considered indicating that the concrete was stiff and not workable for the w/c ratio 0.3 and 0.4 .

(iii) The relationship between STS and CS is affected by the mix ratio and w/c used in producing the PKS concrete.

(iv) PKS Concrete with mix ratio of 1:11/2:3 and 1:2:4 perform better in compression and splitting tensile strength at a w/c of 0.5 and 0.6 .

\section{Acknowledgements}

The Authors acknowledged the efforts of Jimoh Kamaldeen Adebayo for his assistance with the bench works.

\section{References}

Abdullah, A. A. (1984). Basic Strength Properties of Lightweight Concrete Using Agricultural Wastes as Aggregates. Tweight Concrete Using Agricultural Wastes as Aggregates, Proceedings of International Conference on Low-Cost Housing for Developing Countries, Roorkee, India.

Adesina, A., and Atoyebi, O. D. (2020). Effect of crumb rubber aggregate on the performance of cementitious composites: A review Effect of crumb rubber aggregate on the performance of cementitious composites: A review. IOP Conf. Series: Earth and Environmental Science, 445(012032). https://doi.org/10.1088/1755-1315/445/1/012032

Alengaram, U. J., Jumaat, M. Z., \& Mahmud, H. (2008). Ductility Behaviour of Reinforced Palm Kernel Shell Concrete Beams. European Journal of Scientific Research, 23(3), 406-420.

Atoyebi, O D, Aladegboye, O. J., and Odeyemi, S. V. (2018). Evaluation of Laterized Earth Moist Concrete in Construction Works. International Journal of Civil Engineering and Technology (IJCIET), 9(10), 327-333.

Atoyebi, O D, Gana, A. J., and Longe, J. E. (2020). Strength assessment of concrete with waste glass and bankoro (Morinda Citrifolia) as partial replacement for fine and coarse aggregate. Results in Engineering, 6(100124). https://doi.org/https://doi.org/10.1016/j.rineng.2020.100124

Atoyebi, Olumoyewa D, Odeyemi, S. O., Bello, S. A., and Ogbeifun, C. O. (2018). Splitting tensile strength assessment of lightweight foamed concrete reinforced with waste tyre steel fibres. International Journal of Civil Engineering and Technology, 9(9), 1129-1137. https://doi.org/10.1111/j.1532-5415.2007.01543.x

Basri, H. B., M. A. Mannan, and M.F.M. Zain (1998). Concrete using waste oil palm kernel shells as aggregate, Cement and Concrete Research 29 (1999)

BS 8122-2: (1995): Methods of determination of density by British Standard Institution

BS EN 1097-2. (2013). Testing aggregates. Method for determination of aggregate impact value (AIV), British Standards, BSI Group Headquarters, 389 Chiswick High Road, London, W4 4AL, UK, Standards Policy and Strategy Committee.

BS EN 12350-2 (2019): Testing Fresh Concrete by British Standard Institution

BS EN 12620:2002+A1:2008. (2008). Specification for Aggregates from natural sources for concrete. British Standards, BSI Group Headquarters 389 Chiswick High Road, London, W4 4AL, UK, Standards Policy and Strategy Committee.

BS EN 933-1. (2012). Tests for Geometrical Properties of Aggregates - Part 1: Determination of Particle Size Distribution - Sieving Method.

Chandra, S., \& Berntsson, L. (2003). Lightweight Aggregate Concrete, Science, Technology, and Applications (1st ed.). Noyes Publications.

Mannan, M. A., \& Ganapathy, C. (2002). Engineering properties of concrete with oil palm shell as coarse aggregate. Construction and Building Materials, 16(1), 29-34.

Ndoke, P. N. (2006). Performance of Palm Kernel Shells as a Partial replacement for Coarse Aggregate in Asphalt Concrete. Leonardo Electronic Journal of Practices and Technologies, 9, 145-152.

Neville, A. M. (2011). Properties of Concrete (5th ed.). Pearson Education Ltd.

Nigerian Institute for Oil Palm Research (NIFOR). (1989). History, Activities and Achievements. 
NIS 444-1:2003. (2003). Composition, Specifications and Conformity Criteria for Common Cements. Nigerian Industrial Standard, Standard Organisation of Nigeria, Lagos, Nigeria.

Nuhu-Koko, M. K. (1990). The use of Palm kernel shells as aggregates for concrete. 21st Annual Conference of Materials Testing, Control and Research, Federal Ministry of Works, Lagos, Nigeria.

Odeyemi, S. O., Abdulwahab, R., Abdulsalam, A. A., and Anifowose, M. A. (2019). Bond and Flexural Strength Characteristics of Partially Replaced Self-Compacting Palm Kernel Shell Concrete. Malaysian Journal Of Civil Engineering, 31(2), 1-7.

Odeyemi, S. O., Anifowose, M. A., Abdulwahab, R., and Oduoye, W. O. (2020). Mechanical Properties of High-Performance Concrete with Guinea Corn Husk Ash as Additive. LAUTECH Journal of Civil and Environmental Studies, 5(September 2020), 139-154. https://doi.org/10.36108/laujoces/0202/50(0131)

Odeyemi, S. O., Anifowose, M. A., Oyeleke, M. O., Adeyemi, A. O., and Bakare, S. B. (2015). Effect of Calcium Chloride on the Compressive Strength of Concrete Produced from Three Brands of Nigerian Cement. American Journal of Civil Engineering (AJCE), 3(2-3), 1-5. https://doi.org/10.11648/j.ajce.s.2015030203.11

Okafor, F. O. (1988). Palm kernel shell as aggregate for concrete. Cement and Concrete Research, 18(6), 901-910.

Okpala, D. C. (1990). Palm kernel shell as a lightweight aggregate in concrete. Building and Environment, 25(4), 291-296.

Olanipekun, E. A., Oluola, K. O., and Ata, O. (2006). A Comparative study of concrete properties using coconut shell and palm kernel shell as coarse aggregates. Building and Environment, 41(3), 297301.

Olutoge, F. A. (2010). Investigations On Sawdust And Palm Kernel Shells As Aggregate Replacement. ARPN Journal of Engineering and Applied Sciences, 5(4), 7-13.

Oyedepo, O. J., Olanitori, L. M., and Olukanni, E. O. (2015). Investigation of Palm Kernel Shell as Partial Replacement for Aggregate in Asphaltic Concrete. Malaysian Journal of Civil Engineering, 27(2), 223-234.

Teo, D. C. L., Mannan, M. A., Kurian, V. J., and Ganapathy, C. (2007). Lightweight concrete made from oil palm shell (OPS): Structural bond and durability properties. Building and Environment, 42(7), 2614-2621. 